\title{
A stratigraphical basis for the Anthropocene?
}

\section{Colin N. Waters ${ }^{1}$, Jan A. Zalasiewicz ${ }^{2}$, Mark Williams ${ }^{2}$, Michael A. Ellis ${ }^{1}$, \& Andrea M. Snelling ${ }^{3}$}

${ }^{1}$ Environmental Science Centre, British Geological Survey, Keyworth, Nottingham, NG12 5GG UK.

${ }^{2}$ Department of Geology, University of Leicester, Leicester LE 17 RH, UK.

3 NERC Isotope Geosciences Laboratory, British Geological Survey, Keyworth, Nottingham, NG12 5GG UK.

\section{Abstract}

Recognition of intimate feedback mechanisms linking changes across the atmosphere, biosphere, geosphere and hydrosphere demonstrates the pervasive nature of humankind's influence, perhaps to the point that we have fashioned a new geological epoch, the Anthropocene. To what extent will these changes be evident as long-lasting signatures in the geological record?

To establish the Anthropocene as a formal chronostratigraphical unit it is necessary to consider a spectrum of indicators of anthropogenically-induced environmental change and determine how these show as stratigraphic signals that can be used to characterise an Anthropocene unit and to recognise its base. It is important to consider these signals against a context of Holocene and earlier stratigraphic patterns. Here we review the parameters used by stratigraphers to identify chronostratigraphical units and how these could apply to the definition of the Anthropocene. The onset of the range of signatures is diachronous, though many show maximum signatures which post-date1945, leading to the suggestion that this date may be a suitable age for the start of the Anthropocene.

Keywords: Anthropocene, stratigraphy, global environmental change 
The 'Anthropocene' is in many respects a novel potential geological unit. Stratigraphy, which deals with the classification of geological time (geochronology) and material timerock units (chronostratigraphy), has historically defined geological units based upon significant, but temporally distant events. These events are typically, though not exclusively, associated with major changes in the fossil contents of rocks below and above a particular horizon and therefore with the temporal distribution of life-forms. It was only following such observations that new stratigraphical units were proposed and ultimately defined. For example, the major mass extinction at the end of the Permian was used by J. Phillips in 1840 to recognise the beginning of both the Triassic Period and of the Mesozoic Era. The ultimate definition, however, of the base of the Triassic was accomplished only in 2001, when the Global Stratotype Section and Point was taken at the base of a specific bed in a section in Meishan, China, coinciding with the lowest occurrence of the primary marker, the conodont Hindeodus parvus (Yin et al. 2001). In contrast, the Anthropocene was proposed as a term (Crutzen \& Stoermer 2000) before any consideration of the nature of the signature of this new stratigraphical unit was given. For the first time in geological history, humanity has been able to observe and be part of the processes that potentially may signal such a change from the preceding to succeeding epoch.

What are the key 'events' over the last decades to millennia that have the potential to leave a recognisable record in sediments/ice that could be used to define the base of the Anthropocene? The options cover a diverse range of geoscientific fields and need not be restricted to the biostratigraphical tools typically used throughout much of the geological column to define chronostratigraphical units. Potential stratigraphical tools and techniques that may be used to define the base of the Anthropocene include the following (Fig. 1):
1) appearance and increased abundance of anthropogenic deposits;
- artificial anthropogenic deposits
- anthropogenic soils (anthrosols)
- novel minerals and mineraloids
- anthropogenic subsurface structures ("trace fossils")
- anthropogenic modification of terrestrial and marine sedimentary systems

2) biotic turnover;

- megafauna

- reef ecosystems

- microflora

- microfauna

3) geochemical;

- evidence preserved in the cryosphere

- records in speleothems

- organic and inorganic contributions to sediments

4) climate change;

- ocean geochemistry

- oceanic biodiversity

- continental to ocean sediment flux 
- sea-level change

5) catastrophic events;

- radiogenic spikes from nuclear bomb tests/accidents

- volcanic eruption

- meteorite/asteroid (bolide) impact.

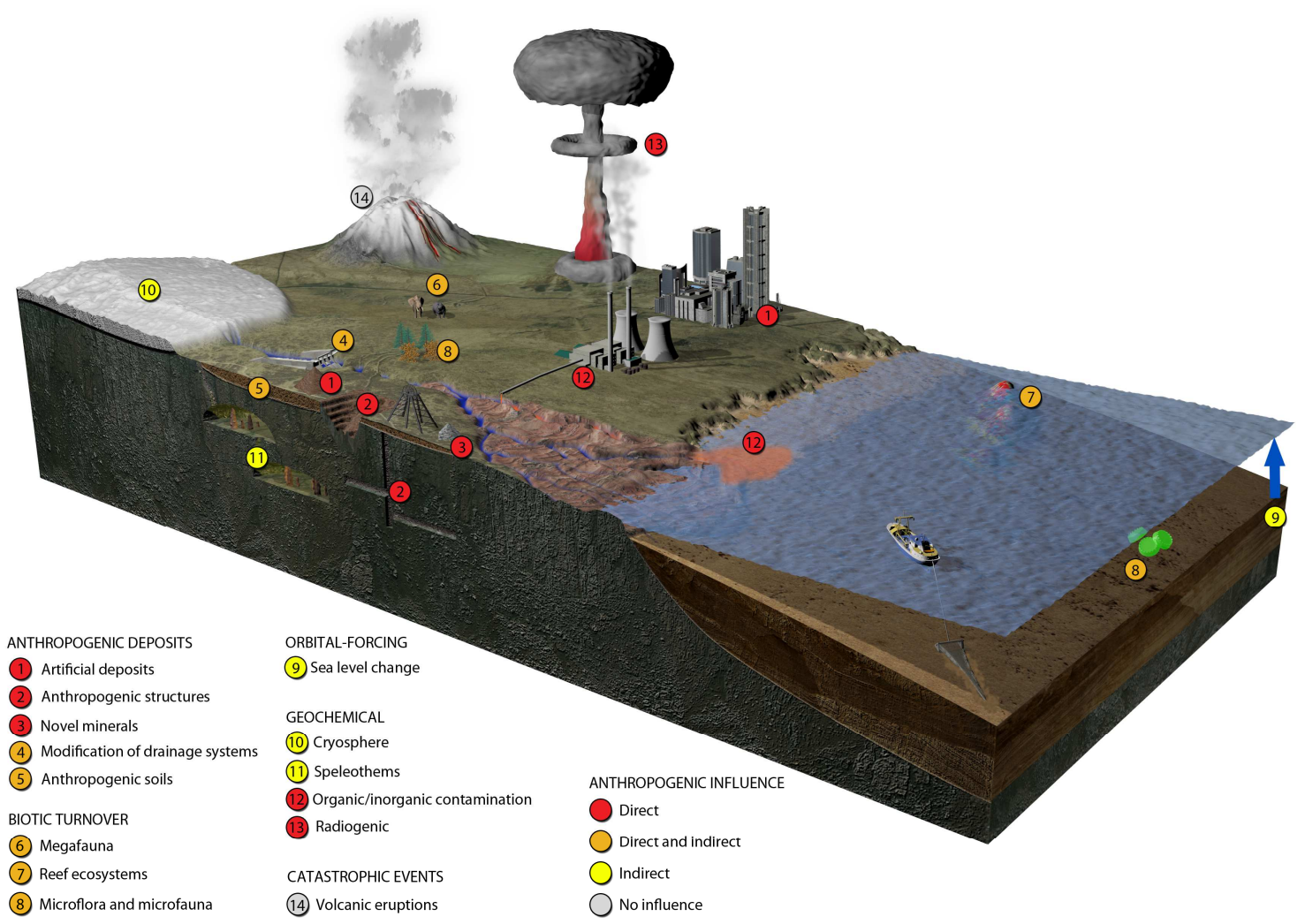

Fig. 1. Examples of key 'events' that could produce stratigraphical signatures that could be used to define the base of the Anthropocene.

The 17 contributions to 'A Stratigraphical Basis for the Anthropocene' mainly cover those events that have been directly the result of humanity's growing influence on the Earth (1 to 3 above) and it is most likely that one or more of these signatures could be used to define the basal boundary of the Anthropocene. In addition, the practical use of tephrochronology, dating historical events through volcanic ash deposits, clearly provides an important stratigraphical tool for quantifying Anthropocene events.

97 In this contribution, we begin by presenting a description of the process by which the 98 Anthropocene is being considered for ratification. We consider the hierarchical 99 stratigraphical level to which the Anthropocene might be applied, or remain a popular but 100 entirely informal unit which exists outside the formal Geological Time Scale. We outline 101 some of the techniques for dating sediments/ice, detail the three main suggestions 102 forwarded as potential ages for the start of the Anthropocene: pre-Industrial Revolution; 
1800 and the start of the Industrial Revolution in parts of the planet; and 1950, the 'Great Acceleration' in global economic activity following World War II (Steffen et al. 2007).

105 Potential future ages are also considered. A glossary of commonly used terms is also

\section{Process of ratification of the proposed Anthropocene Epoch}

The Anthropocene Working Group (AWG) of the Subcommission on Quaternary Stratigraphy (SQS) was established in 2009 to consider the informal proposal that we no longer live in the Holocene Epoch, but in a time period which should be referred to as the Anthropocene. The AWG is tasked to assess evidence that there are environmental signatures preserved in sedimentary or cryospheric successions that can be attributed uniquely to the Anthropocene. If accepted, the AWG would need to define a Global Stratigraphic Section and Point (GSSP or 'golden spike') in a type locality, or to define a Global Standard Stratigraphic Age (GSSA or numerical age), that defines the Holocene/Anthropocene boundary.

The process by which a new epoch can be ratified is described by Finney (2013), who also raises a series of pertinent questions that he feels need to be addressed by the AWG, though many of these questions are unique to the Anthropocene. Zalasiewicz et al. (2014 a) describe some of the problems related to the short time-scales inherent in the definition of the Anthropocene, such as bioturbation and pedogenesis. The ability to locate a boundary through counting varves in sediments or layers in ice-core to the nearest year, or at least decade, would provide a scale of rigour not previously faced during the definition of older chronostratigraphical boundaries, where potential diachroneity of many thousands of years cannot be resolved by current dating techniques.

\section{Status as Epoch or Age}

Given the hierarchical nature of chronostratigraphy (Salvador 1994), the higher the rank of the Anthropocene, the greater the change has occurred between it and the previous stratigraphical unit (Gibbard \& Walker 2013). The term proposed, even if by accident (Steffen $\boldsymbol{e t}$ al. 2004), implies by use of the ending 'cene' to be of Epoch status. Stages/ages typically end in 'ian' and as such if the new division was considered to be of this rank would need to be named as Anthroposian, or similar. To warrant Epoch status the scale of changes in key criteria (biostratigraphical, sedimentological and geochemical) need to be of comparable magnitude to those used as evidence for earlier Epoch boundaries, such as that between the Pleistocene and Holocene (Gibbard \& Walker 2013). Hence, consideration as a potential Epoch has the scientific benefit of overtly testing the implicit hypothesis in Crutzen (2002): that the Holocene, defined by fundamental aspects of the Earth system, has terminated.

The Holocene is being considered to be divided into three Stages/Ages along the lines of 'Early', 'Mid' and 'Late' Holocene, with internal boundaries at $8.2 \mathrm{ka}$ and $\sim 4.2 \mathrm{ka}$ (Walker et al. 2012). This does not leave open the option of the Anthropocene to be considered a Late Holocene Stage/Age. 
The base of the Quaternary Period is formally defined at a GSSP (Gibbard $\boldsymbol{e t}$ al. 2010), although a concept associated with this definition is that it also reflects the onset of the major northern hemisphere glaciation. Wolff (2013) faces the possibility that the end of the sequence of northern hemisphere glaciations should signal the end of the Quaternary, but he suggests that current evidence does not preclude glacial inception in the future (timescales of $10 \mathrm{ka}$ to $100 \mathrm{ka}$ ). Levels of atmospheric $\mathrm{CO}_{2}$ (Lüthi et al. 2008) $\mathrm{CH}_{4}$ (Loulergue et al. 2008) and $\mathrm{N}_{2} \mathrm{O}$ (Schilt et al. 2010) in ice cores are at levels higher than observed for the last $800 \mathrm{ka}$ (Wolff 2013), and in the case of $\mathrm{CO}_{2}$ at levels unprecedented since the warmer Pliocene Epoch (see Haywood et al. 2011). Such signatures would distinguish the Anthropocene from the Holocene and part, if not all of the Pleistocene.

Between the 1500's to 1700's the number of species extinctions (plants and animals) ran at less than 50 per century, with extinctions rising to 125 in the 1800 's and 500 in the 1900's (Barnosky 2013). Barnosky (2013) concludes that although extinction rates are elevated at 3-12 times normal background rates, less than $1 \%$ of species have become extinct. For vascular plants, at least 5\% of native species appear to have been lost across half of the terrestrial biosphere, but in many cases native plant species are able to maintain viable populations even in heavily managed anthropogenic biomes (Ellis $e t$ al. 2012). Therefore, at present we are not experiencing something equivalent to the Big Five mass extinctions, where an estimated $75-96 \%$ of known species became extinct, or as regards large terrestrial vertebrates the Late Quaternary Megafauna Extinction near the Pleistocene-Holocene boundary (Barnosky et al. 2011, Barnosky 2013). This suggests that, as Gibbard \& Walker (2013) contend, the Anthropocene does not provide a biostratigraphical signature equivalent to the epoch status defined for the Holocene. However, this extinction threshold would be exceeded in the near future and in excess of $75 \%$ species loss can be predicted within 300-500 years at current extinction rates, unless conservation methods become markedly more effective (Barnosky et al. 2011, Barnosky 2013). This would produce a biohorizon on a scale of the Big Five mass extinctions and if this is to become reality, the Anthropocene would arguably be of Period/System scale. Extinctions are not the only indicator of biostratigraphy, though, as the changes to assemblages through species invasions (Barnosky 2013) are now considerable, globally expressed and effectively permanent.

\section{Absolute and relative dating techniques}

Climatostratigraphy, or use of contrasting climatic conditions to characterise stratigraphical units, is of primary importance for correlation within Quaternary successions (Gibbard \& Walker 2013). The Quaternary is subdivided into Marine Isotope Stages (MIS 1-104), reflecting orbitally-forced cooling (glacials) and warming (interglacials) of the Earth's climate, the ages of which have been accurately constrained (Lisiecki \& Raymo 2005). This is evident through the $\delta^{18} \mathrm{O}$ signature of marine biogenic calcite, which reflects the increased incorporation of the light ${ }^{16} \mathrm{O}$ into expanding icesheets (Shackleton \& Opdyke 1973). MIS 1 ranges from the present to $11.7 \mathrm{ka}$, coinciding with the Holocene Epoch, the current interglacial. The Anthropocene does not fit within such a definition and clearly MIS stages are insufficient when it comes to dating anthropogenic deposits. It is the disruption of such quasi-periodic signals that 
194

makes the Anthropocene distinctive, potentially to the point that we no longer exist within a regime of orbitally-dominated climate change. Alternative means need to be found of characterising and defining the Anthropocene, as discussed below.

Radiometric dating has become an increasingly precise tool for determining the absolute age of chronostratigraphical boundaries, e.g. the base of the Triassic is bracketed by two dated volcanic-ash clays and constrained at $252.16 \pm 0.2 \mathrm{Ma}$ (Shen et al. 2010), an error of only $0.001 \%$ of the total age. A number of radiometric techniques used to determine Quaternary chronology are here considered for their suitability for dating the Anthropocene. Radiocarbon $\left({ }^{14} \mathrm{C}\right)$, although routinely used by the archaeological community to date organic remains has insufficient resolution. It has an error of several decades, which is unsuitable if the beginning of the Anthropocene is chosen to have occurred during the last 200 years (Table 1). Radioisotopes such as ${ }^{137} \mathrm{Cs}$ and ${ }^{90} \mathrm{Sr}$ are useful time markers that can be potentially linked to specific and temporally constrained emissions, are laterally extensive and with a short half-life (Table 1), but in areas of low fallout these radionuclides may already be approaching the limits of detection (Hancock et al. 2013) and ice core $\beta$-radioactivity on isotopes (Dibb et al. 1990) is unsuitable for dating signatures even for the start of the Industrial Revolution (Wolff 2013). Laminacounting techniques used in conjunction with ${ }^{210} \mathrm{~Pb}-{ }^{226} \mathrm{Ra}$ or ${ }^{234} \mathrm{U}^{230} \mathrm{Th}$ radiometric dating (Table 1) is potentially of importance in the context of dating speleothems (Fairchild \& Frisia 2013). ${ }^{210} \mathrm{~Pb}$ may also be useful for dating microfauna and microflora (Wilkinson et al. 2014), marine or lacustrine clay sediments and peats. In the more distant future, dating techniques may rely upon more long-lived isotopes, such as ${ }^{239} \mathrm{Pu}$ and ${ }^{240} \mathrm{Pu}$ (Table 1), which also bind strongly to soil and sediment particles (Hancock et al. 2013). The longer-lived nature and greater abundance of ${ }^{239} \mathrm{Pu}$ makes it the preferred chronometer, and in many regions the signal is likely to be detectable in sediments for $100 \mathrm{kyr}$ or longer (Hancock et al. 2013).

Radiogenic methods such as Luminescence and Electron Spin Resonance (ESR) are relatively new techniques becoming increasingly used by archaeologists and Quaternary geoscientists. The Luminescence method dates the last time an object was heated (particularly useful for pottery) or exposed to sunlight (potentially useful to delimit burial of artificial deposits). It can provide dates that range from 10 years up to $1 \mathrm{Myr}$, but has comparatively low accuracy, with errors of typically 5-10\% (Duller 2008). ESR dates, mainly used on corals, speleothems, teeth and bone, range from a few thousand years to $300 \mathrm{kyr}$ and so may be of little practical use for dating the Anthropocene if it is to fall within the last two centuries.

Cosmogenic Radionuclides (CRNs) dating relies upon the accumulation of ${ }^{3} \mathrm{He},{ }^{10} \mathrm{Be}$, ${ }^{21} \mathrm{Ne},{ }^{26} \mathrm{Al}$ and ${ }^{36} \mathrm{Cl}$ in response to the duration of exposure of the upper $1-2 \mathrm{~m}$ of sedimentary deposits or ice to cosmic rays (Gosse \& Phillips 2001). The technique has the ability to date the timing of surface exposure through excavation using CRN production (range 100 years to $5 \mathrm{Ma}$ ) or the date of burial through decay of CRNs (range of $\sim 0.1-5 \mathrm{Ma}$ ) (Akçar et al. 2008). 
Radiometric dating of volcanic ash deposits has become an intrinsic part of the characterisation of GSSPs. For example, the base of the Triassic Period at the Meishan GSSP is bracketed by dated volcanic-ash clays $18 \mathrm{~cm}$ below and $8 \mathrm{~cm}$ above the base of the Triassic (Shen et al. 2010). Such regionally extensive deposits could be used as marker bands to demarcate the base of the Anthropocene. Each eruption can be characterised by a distinctive geochemical 'fingerprint' and a combination of radiometric dating and the historical documentation of events can lead to age constraints at annual resolution (Smith 2013). Smith (2013) identifies a number of useful marker tephra deposits, but suggests, in agreement with Zalasiewicz et al. (2008) that the $1815 \mathrm{CE}$ eruption of Tambora, Indonesia, the largest eruption in recorded history would be most suitable of such markers, particularly as it aligns with the early phase of the Industrial Revolution. Although the ash deposits were spatially restricted and constrained by wind direction, the effects are evident globally with development of associated sulphate peaks within ice cores and temporary climatic events evident in tree rings (Delmas 1992, Briffa et al. 1998, Smith 2013).

\begin{tabular}{|c|c|c|c|c|}
\hline Isotope & $\begin{array}{l}\text { Half-life } \\
\text { (years) }\end{array}$ & $\begin{array}{l}\text { Acceptable } \\
\text { range }\end{array}$ & Accuracy & Suitability \\
\hline${ }^{14} \mathrm{C}^{(1)}$ & $5568 / 5730$ & $200-60 \mathrm{kyr}$ & Decades-centuries & $\begin{array}{l}\text { Peat, wood, charcoal, } \\
\text { bone, shells, soil, ice core, } \\
\text { coral etc. (Pre-Industrial) }\end{array}$ \\
\hline${ }^{137} \mathrm{Cs}^{(2)}$ & $\begin{array}{l}30.17 \pm \\
0.03\end{array}$ & $\begin{array}{l}1954 \text { AD- } \\
\text { Present }\end{array}$ & $\begin{array}{l}\text { Annual (if linked to } \\
\text { known emissions) - } \\
\text { decades }\end{array}$ & $\begin{array}{l}\text { Terrestrial-marine } \\
\text { sediments } \\
\text { (Mid } 20^{\text {th }} \text { Century) }\end{array}$ \\
\hline${ }^{90} \mathrm{Sr}{ }^{(3)}$ & 28.79 & $\begin{array}{l}\text { 1950s AD- } \\
\text { Present }\end{array}$ & $\begin{array}{l}\text { Annual (if linked to } \\
\text { known emissions) - } \\
\text { decades }\end{array}$ & $\begin{array}{l}\text { Terrestrial-marine } \\
\text { sediments } \\
\text { (Mid } 20^{\text {th }} \text { Century) }\end{array}$ \\
\hline${ }^{226}{ }^{210} \mathrm{Ra}^{(4)}$ & $\begin{array}{l}22.3 \\
\left({ }^{210} \mathrm{~Pb}\right)\end{array}$ & $<150 \mathrm{yr}$ & Decades & $\begin{array}{l}\text { Carbonates, speleothems, } \\
\text { microflora, microfauna } \\
\text { (Mid 20 } 0^{\text {th }} \text { Century) }\end{array}$ \\
\hline${ }^{230} \mathrm{Th}^{234}{ }^{(4)}$ & 245560 & $<500 \mathrm{kyr}$ & Centuries & $\begin{array}{l}\text { Carbonates, speleothems, } \\
\text { bone, teeth } \\
\text { (Pre-Industrial) }\end{array}$ \\
\hline${ }^{239} \mathrm{Pu}{ }^{(5)}$ & 24110 & $<100 \mathrm{kyr}$ & $\begin{array}{l}\text { Centuries; annual if } \\
\text { linked to known } \\
\text { emissions) }\end{array}$ & $\begin{array}{l}\text { Soil, sediment (Mid 20 } \\
\text { Century) }\end{array}$ \\
\hline${ }^{240} \mathrm{Pu}{ }^{(5)}$ & 6563 & $<30 \mathrm{kyr}$ & $\begin{array}{l}\text { Centuries; annual if } \\
\text { linked to known } \\
\text { emissions }\end{array}$ & $\begin{array}{l}\text { Soil, sediment (Mid } 20^{\text {th }} \\
\text { Century) }\end{array}$ \\
\hline
\end{tabular}

Table 1. Commonly used radiometric dating techniques and their applicability to dating Anthropocene deposits/artefacts. Text in italics indicates which of the three main options of the age of the Anthropocene could be most usefully dated using the respective isotopes. ${ }^{(1)}$ Stuiver \& Polach (1977); ${ }^{(2)}$ Unterweger (2013); ${ }^{(3)}$ Browne (1997); ${ }^{(4)}$ Elert 
Prior to the introduction of radiometric dating techniques in the $20^{\text {th }}$ century, the relative age of deposits was constrained through biostratigraphy, which has formed the basis for defining most pre-Quaternary chronostratigraphical units (e.g. Gradstein et al. 2012). Assemblage and abundance biostratigraphical zones, based upon mixes of native and non-native species in both terrestrial and marine settings and lineage zones, based on the evolution of crop plants, are likely to be most useful in defining the Anthropocene (Barnosky 2013). Interval-zones based upon extinctions over recent centuries are of limited use, as most extinct species were formerly not widespread and/or unlikely to leave a fossil record (Ager 1993, Barnosky 2013). Biostratigraphical zones used to recognise chronostratigraphical boundaries are diachronous to some degree as new taxa take time to extend their distribution from a single source origination (Barnosky 2013). Furthermore, there appears to be a time-lag between the onset of anthropogenic activity and the resultant influence upon microbiota (Wilkinson et al. 2014). With a deep-time perspective, these diachroneity and time-lag effects fall within the range of error of most radiometric and biostratigraphic dating techniques, and are not considered significant. For definition of the base of the Anthropocene, which is likely to be resolved at annual or decadal accuracy, such diachroneity severely limits the use of biostratigraphy in our current proximal view of events, but it is likely to become negligible in the future use of biostratigraphy as a tool for recognising the Anthropocene.

Human artefacts, routinely used as an indicator of age in archaeological investigations, could be used as an equivalent of the geological "type-fossils", with potentially greater resolution than biostratigraphical fossils (Barnosky 2013, Edgeworth 2013 \& Ford $\boldsymbol{e t}$ al. 2014). The evolution of these artefacts, which may be considered human-produced trace fossils (Barnosky 2013, Williams et al. 2013) or technofossils (Zalasiewicz et al. 2014b), is a function of cultural dynamics rather than natural selection (Edgeworth 2013). These artefacts are prone in recent decades, certainly since the 1950's, to evolve from invention (equivalent to the biostratigraphical First Appearance Datum or FAD) to global distribution (equivalent to biostratigraphical acme) and then to obsolescence (equivalent to biostratigraphical rarity) within comparatively few years, as a function of the globalisation of trade. Also, the lithological composition of wastes in landfills is equivalent to the biostratigraphical assemblage zone and can be indicative of age, as illustrated by Ford $\boldsymbol{e t}$ al. (2014). Such artefacts and anthropogenic facies variations provide a very high-resolution (potentially annual to decadal) tool for dating deposits (Zalasiewicz et al. 2014b). However, the long-term preservation potential of such artefacts and anthropogenic sediments will be variable (Price et al., 2011, Ford $\boldsymbol{e t}$ al. 2014), such that only part of today's wide range of artefacts will be recognisable in the distant future.

Annual layer counting techniques can produce very high precision dating, potentially to annual resolution. Potential techniques include dendrochronology, coral laminations, seasonally layered sediments in glacially influenced lakes, speleothem layers and ice cores. Details of the various techniques are summarised in Bradley (1999). Dendrochronology not only has anchored chronologies extending throughout most of the Holocene; the pattern of rings is indicative of local climatic conditions within temperate zones and can also potentially be used to determine wood provenance. 
309 There is no single global palaeomagnetic spike that could be used to define the base of 310 the Anthropocene (Snowball et al. 2013). However, Snowball et al. (2013) note that there is a global event, most strongly developed in mid to high latitudes coincident with a low in dipole latitude and peak in dipole moment at $2.55 \mathrm{ka}$ cal. BP (the European ' $\mathrm{f}$ event') which may be a potential chronostratigraphic marker. A new archaeological dating technique uses high frequency secular variation of the geomagnetic field. This permits annual to decadal age resolution for Fe-oxide bearing materials, including artefacts such as fired ceramics, formed in the last few thousand years (Snowball et al. 2013).

The significance of the history of excavation or 'cut' in archaeology in helping to determine the history and timing of events (Edgeworth 2013) has analogues in the use of geological unconformities to constrain the timing of events through allostratigraphy (Ford et al. 2014). It is clear that the complexity of such 'cut' surfaces, though of value at the local scale, makes regional-scale correlation of erosional/non-depositional surfaces almost impossible. The only unconformity that can be correlated with any certainty is the bounding surface between the lowermost artificial deposits from underlying natural deposits that pre-date human modification of the immediate landscape. This bounding surface is highly diachronous overall, although times of marked expansion of cities (e.g. post the mid-twentieth century) represent traceable stratigraphic 'plateaux'.

\section{Definition of a boundary stratotype or numerical age}

The International Stratigraphic Guide (Hedberg 1976, Salvador 1994) requires that all major chronostratigraphical subdivisions are defined with reference to boundary stratotype localities in sedimentary reference sequences, designated as Global Stratigraphic Sections and Points (GSSPs). Definition of the Holocene differed in that the GSSP was defined in ice core rather than a sedimentary deposit (Walker et al. 2009), but essentially followed principles outlined in the International Stratigraphic Guide. Zalasiewicz et al. (2014 a) review how an Anthropocene signature may be recognized in a range of terrestrial and marine settings. This is helpful when considering potential environments to seek the location of a GSSP, if a traditional route to defining the base is to be chosen.

It has recently been argued by Smith et al. (2014) that the precision in radiometric techniques in the determination of the age of chronostratigraphical boundaries is such that definition of a GSSP in a single section based upon the evolution of a specific indicator faunal/floral species should be replaced by a Global Standard Stratigraphic Age (GSSA or numerical age). With the definition of the base of the Anthropocene possibly at a time of tens to hundreds of years before present, the resolution of dating techniques is at least decadal if not annual and definition of a GSSA at a specific year is feasible and arguably preferable to using a proxy indicator (Zalasiewicz et al. 2011). Smith et al. (2014) propose that in general GSSAs should be decided based upon a spectrum of signatures. In this section we consider four distinct options for the potential placement of the base of the Anthropocene: (1) pre-Industrial Revolution age; (2) Industrial Revolution age; (3) mid 20th century age; and (4) the future. 


\section{Evidence for a pre-Industrial Revolution age}

356 Gibbard \& Walker (2013) characterise the Holocene Epoch as a time in which there has been a progressive increase in the prominence of humans as an agent influencing natural environments and processes. They argue that the anthropogenic signature is a hallmark of the current Holocene interglacial and this is distinct from previous interglacials that occurred during the Pleistocene. They contend that it is not then possible to further use the activities of humans to define a post-Holocene Epoch.

If the Anthropocene is to be considered the Epoch that humanity has created, it is evident that human influence on the planet in the form of directly deposited terrestrial anthropogenic deposits are markedly diachronous in their nature, are laterally impersistent, may include numerous disconformities, may be reworked by continued human landscape modification and ultimately have relatively low propensity for preservation in the geological record (Ford et al. 2014). The earliest signatures approximate to the onset of the Holocene with Edgeworth (2013) describing a significant and long-lived urban development which commenced some 11 ka BP (Fig. 2). It may be misleading, though, to think of the Anthropocene just as the 'human epoch'. The key factor is the level of geologically significant global change, with humans currently happening to be the primary drivers: future, potentially yet more pronounced change (cf. Wolff 2013) may be primarily driven by Earth system feedbacks such as methane release, and yet would still clearly be part of the same phenomenon.

Anthropogenic influence is not necessarily first seen through urban development. More often it is evident through the initiation of agricultural practices, with forest clearances increasing atmospheric $\mathrm{CO}_{2}$ levels from $8 \mathrm{ka} \mathrm{BP}$ and cultivation and irrigation techniques increasing atmospheric $\mathrm{CH}_{4}$ levels about 5 ka BP (Ruddiman 2003, 2005; Fig. 2). Prior to $1700 \mathrm{CE}$, the deforestation was almost exclusively of temperate forests (Food and Agricultural Organisation of the United Nations 2010). However, $\mathrm{CO}_{2}$ and $\mathrm{CH}_{4}$ concentrations, trends and rates of change fall within the range recorded in ice core over the $800 \mathrm{kyr}$ prior to $1800 \mathrm{CE}$, suggesting there is no strong evidence that humanity has driven these cycles outside of their natural range prior to the Industrial Revolution (Wolff 2013). Also, it has been argued that the rise in $\mathrm{CH}_{4}$ levels over the last $5 \mathrm{kyr}$ does not need to be linked to changes in agriculture, but could be the product of natural changes in the Earth's orbit associated with precession-induced modification of seasonal rainfall in the Southern Hemisphere tropics (Singarayer et al. 2011).

Human indirect influence upon rivers provides a recognisable signature in the fluvial system, including coastal deltas. This is associated with increasing sediment loading in response to erosion due to deforestation, animal grazing and changing agricultural practices, mill development, transport networks and the influence upon global climate systems including effects such as increased precipitation intensity or desertification and sea-level rise resulting in coastal inundation (Merritts et al. 2011; Syvitski \& Kettner 2011). In particular, the impact of introduction of intensive agricultural practices is noted as causing a widespread stratigraphical marker across many continents associated with a transition from basal gravels with organic channel fills to a thick capping of sandy silt 
(Brown et al. 2013). In two nearby river systems in the UK this boundary is dated at $3600-4400$ years cal BP and 1300-220 years cal BP, showing that this boundary is significantly time-transgressive and makes it difficult to consider as a sedimentary

Mineral magnetic studies in lake sediments, which are a strong indicator of deforestation events and soil erosion, suggest a complex and diachronous history of clearance (Snowball et al. 2013). The largest mineral magnetic signatures associated with catchment disturbance during expansion of agriculture in Europe began around $1100 \mathrm{CE}$ \pm 100 years (Fig. 2) with similar signatures evident in China and Mexico at broadly the same time, though they are dependent on cultural and not geological controls and are not isochronous (Snowball $\boldsymbol{e t}$ al. 2013). Anthropogenic disturbance of soil horizons is also clearly recorded in speleothems and is also notably diachronous (Fairchild \& Frisia 2013). Although initiation of forest clearances can be discounted as an adequate signature for recognising the base of the Anthropocene, it is clear that the expansion and intensification of agricultural land-use has resulted in extensive clearances of native vegetation and megafauna, and replacement with domesticates in excess of $3 \mathrm{ka}$ ago (Ellis et al. 2013). The onset of these agricultural practices also resulted in significant modifications of fluvial systems, especially the rapid siltation and increase in sedimentation rate (Dearing \& Jones 2003, Poirier et al. 2011).

The influence of humanity on the generation of soils is vast. Anthropogenic influence includes increasing atmospheric $\mathrm{CO}_{2}$ leading to acidification, addition of lime or fertilizers, management of biota through insecticides and herbicides, physical mixing and movement of soils through ploughing and accelerating soil-forming processes (Richter 2007). It has been suggested that the base of such an extensive anthropogenic soil horizon could make a suitable 'golden spike' at $\sim 2$ ka BP (Certini \& Scalenghe 2011). However, as for anthropogenic deposits, the age of onset of significant development of anthrosols is highly diachronous. For example, the charcoal-enriched 'terra preta' of the Amazon Basin is somewhat younger, potentially up to 500 BCE (Woods 2008). Much of Europe includes evidence for development of plaggen soils, potentially up to $4 \mathrm{ka}$ BCE in age (Simpson 1997), but mainly the product of a type of farming cultivation during the medieval period and post-medieval times (Edgeworth 2013). Soils have low preservation potential and represent an open system prone to modification and are probably the product of numerous events or phases of modification, which are still ongoing. Consequently, Gale \& Hoare (2012) and Zalasiewicz et al. (2014 a) argue that the resolution of the age of the base of gradational soil horizon is not suitable to define the Anthropocene.

Human impacts on diatom assemblages in lakes, the product of eutrophication and/or alkalisation linked to deforestation and introduction of agriculture, extend back at least 5 kyr (Wilkinson et al. 2014; Fig. 2). Similarly, changes to land use and land cover and the resultant increase in soil erosion and transport of sediment into the near-shore setting result in changes to foraminiferal assemblages considerably earlier than other environmental drivers (Wilkinson $\boldsymbol{e t}$ al. 2014). The impact of humans on coral reefs was minimal during the early Holocene, with first evidence of decreasing ecological diversity 
of the large marine herbivores and carnivores beginning around $3.5 \mathrm{ka}$ BP (HoeghGuldberg 2014; Fig. 2).

It is clear that there are major anthropogenic signatures evident during pre-Industrial Revolution times. However, the range of signatures, their magnitude and spatial extent are typically less than that evident during later times. The timing of these impacts overall is more markedly diachronous across the Earth at the scale of our perspective and a single isochronous marker is not apparent prior to the Industrial Revolution.

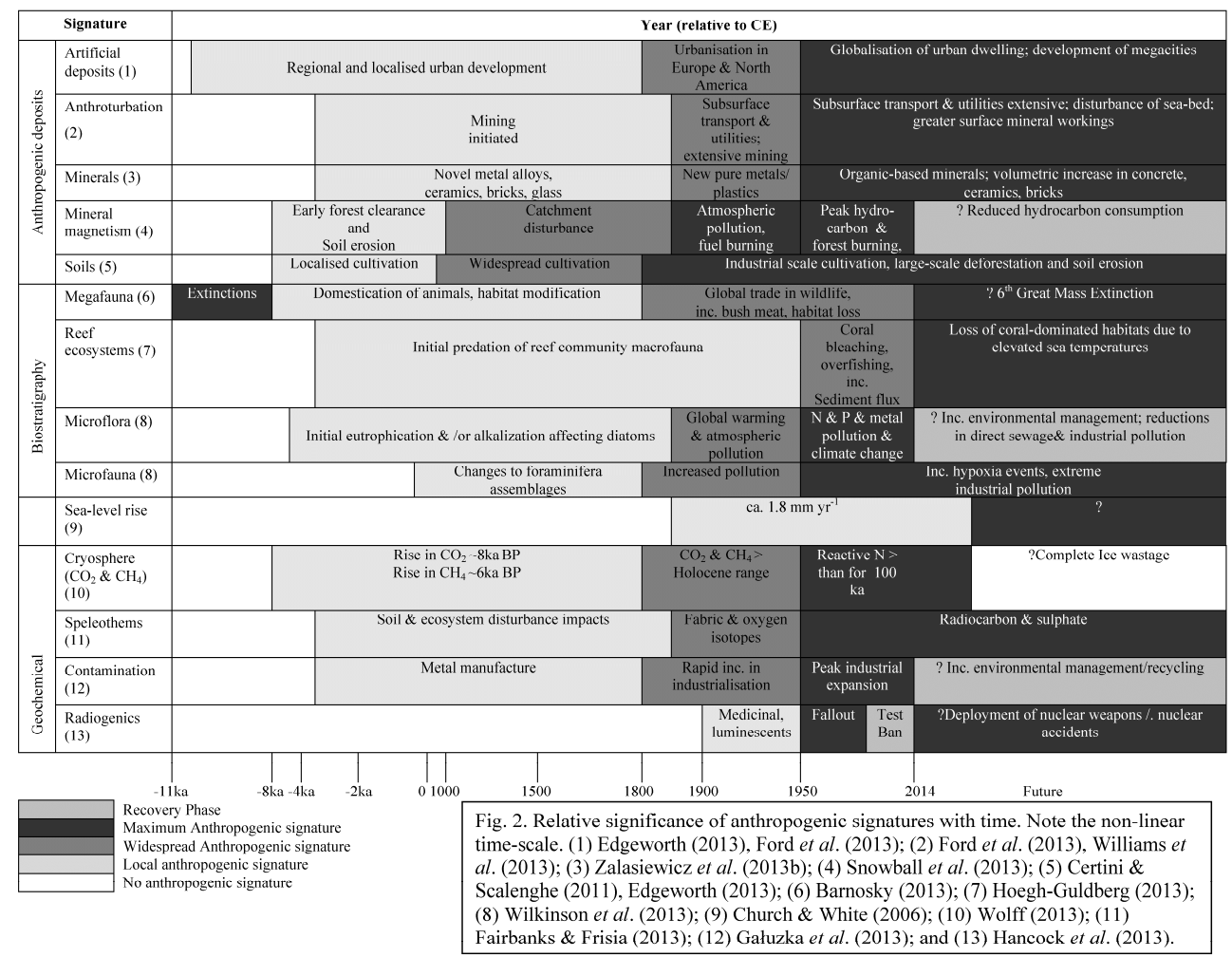

Fig. 2. Relative significance of anthropogenic signatures with time. Note the non-linear time-scale. (1) Edgeworth (2013), Ford et al. (2014); (2) Ford et al. (2014), Williams et al. (2013); (3) Zalasiewicz et al. (2013); (4) Snowball et al. (2013); (5) Certini \& Scalenghe (2011), Edgeworth (2013); (6) Barnosky (2013); (7) Hoegh-Guldberg (2014); (8) Wilkinson et al. (2014); (9) Church \& White (2011); (10) Wolff (2013); (11)

\section{Evidence for an Industrial Revolution age}

Early descriptions of the Anthropocene argued in favour of it starting coincident with the al. 2008). Gibbard \& Walker (2013) consider the clearest marker horizon is a rise in atmospheric $\mathrm{CO}_{2}$ levels above any previous Holocene level from around $1750 \mathrm{CE}$, 470 coincident with the start of an upward rise in $\mathrm{CH}_{4}$ and $\mathrm{N}_{2} \mathrm{O}$ (Fig. 2), though it is important to recognise that this is not directly observed in the rock record. In the ice record, the 
termination of the 'Little Ice Age', a time of modest cooling mainly of the Northern Hemisphere from about 1350 to 1850 CE (Solomon et al. 2007), may be a response to that change in atmospheric composition. Changes in the chemical and physical properties of speleothems (Fairchild \& Frisia 2013) can be linked to the start of this climate amelioration (Fig. 2).

Gibbard \& Walker (2013) argue that although the $\mathrm{CO}_{2}$ signature is recognised globally, including within polar ice cores (Lüthi et al. 2008, Wolff 2013), the cause of the signature reflects industrialisation in only a small part of the Earth, mainly western Europe and eastern North America. This is, however, not an argument raised against the definition of the K-T boundary marking the base of the Cenozoic. Here, the crater associated with bolide impact is only $180 \mathrm{~km}$ across, but the signature of this impact through tektites, the iridum-rich clay layer, climatic change and biotic extinctions was global. Barnosky (2013) contends that when all traces of humanity are considered it forms a boundary layer more widespread than the iridium layer used to recognise the K-T boundary.

The onset of the Industrial Revolution (Fig. 3) resulted in a marked change in the characteristics of anthropogenic deposits (Price et al. 2011, Ford et al. 2014). These include: increased use of building and construction materials; increased exploitation of subsurface deposits; widespread inclusion of processed metals and associated manufactured goods; increased human activities at depth, either for mineral exploitation or subsurface infrastructure. However, the onset of the Industrial Revolution is diachronous, not reaching many developing countries until the middle of the $20^{\text {th }}$ century (Fig. 3) and consequently Gibbard \& Walker (2013) argue it should not be used as a criterion for defining the Anthropocene.

Williams et al. (2013) propose that the base of the Anthropocene should coincide not with the start of the Industrial Revolution, but with the radical evolution of the urban environment in the mid- $18^{\text {th }}$ century. The increased size of conurbations resulted in the need to evolve subsurface transport and sewerage systems in order to keep them functioning. Such subsurface developments have greater long-term preservation potential than surface urban deposits, but the cross-cutting, non-stratiform nature of these subsurface structures precludes their use in recognition of a traditional GSSP. Williams et al. (2013) use a particular event, the inception in London of the first Metro system in 1863, as the criterion for defining the start of the Anthropocene. Williams et al. (2013) compare the increased complexity of the urban environment to be analogous to the increasing complexity of the trace fossils used to define the base of the Cambrian System. Such comparisons to an extent diminish some of the arguments made against definition of the base of the Anthropocene. The base of the Cambrian was recognised initially through a concept of increasing biological complexity and ultimately one ichnospecies was chosen to represent this changing complexity. This first appearance has ultimately proved to be diachronous over hundreds of thousands of years and sections where this transition can be observed are few. In contrast, the complex urban environment has taken only decades to promulgate globally and now covers about $1 \%$ of the Earth's surface. This suggests that while the location of a worldwide, precisely synchronous boundary for 
the Anthropocene is challenging, it is no less so in consideration of existing 518 chronostratigraphical units.
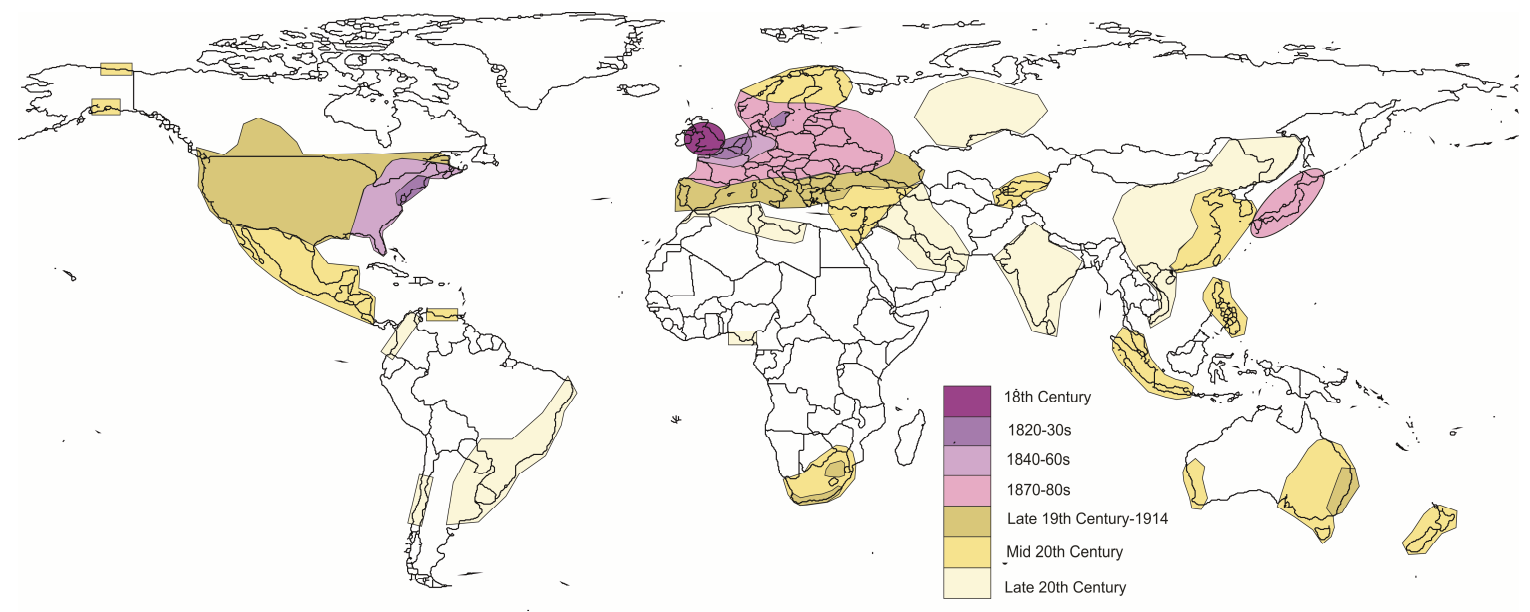

Fig. 3. Map showing the approximate age for the commencement of the Industrial Revolution and subsequent industrialization across the planet. This is a subjective event, here interpreted as the widespread growth of mechanisation in respect to manufacturing, transport and innovation.

In European lakes, diatom assemblages show significant changes in response to humaninduced acidification between 1800-1850, with the first evidence of eutrophication in these lakes between 1850 and 1900 (Battarbee et al. 2011, Wilkinson et al. 2014). This signature is also widespread in Arctic, northern European and North American lakes with prominent changes to diatom assemblages since $\sim 1850$, inferred to be a response to global warming and atmospheric pollution (Fig. 2), but that the timing varied between regions and lakes (Wilkinson $\boldsymbol{e t}$ al. 2014). Whereas, in the oceans, increased nitrogen fixation and elevated concentrations of soluble iron due to increased deposition of ironrich desert dust since 1870 caused intensified growth of phytoplankton (Gałuszka et al. 2013).

In terrestrial environments there was an initial introduction of new plants and domestic animals from the 1500's marking the early age of global exploration and trade, although introduced species in Australasia began mainly in the 1800's (Barnosky 2013). There were significant introductions of alien plant species from the 1800's in many continents (Barnosky 2013), coinciding with scientific investigations during the Enlightenment, the notable British attempts to develop plantations of important exotic commercial plants within their colonies and the increased interest in horticulture. It is a feature of regional plant species richness that the losses of native species are more than offset by the increases in exotic species (Ellis et al. 2012). Globally, the percentage abundance of humans and domestic animals increased relative to wild megafauna in the 1750's, with a second acceleration in the mid-20 $0^{\text {th }}$ century (Barnosky 2013). 
The relationship of black magnetic spherules and atmospheric pollution through fossil

551 fuel burning results in increased magnetic mineral abundance in sediments associated

552 with the Industrial Revolution (Snowball et al. 2013). This is expressed by magnetic susceptibility or isothermal remanent magnetisation and is particularly preserved in peat bogs, soils, lakes, coastal and offshore sediments. They often occur in association with increased heavy metal concentrations. These particles first become abundant in England and eastern seaboard of North America around 1800, and a spread of industrial sources during the $19^{\text {th }}$ century. The largest number of sites shows initial increases of magnetic pollution particles forming an 'AD 1900-event', representing an expression of major fuel burning in these industrialized areas (Locke \& Bertine 1986, Snowball et al. 2013;

Fig.1). However, in other parts of the world signatures appear later, e.g. 1950's in eastern Asia (Snowball et al. 2013), noting also that there is a 100 year lag in the appearance of these magnetic pollution signatures in lake sediments.

\section{Evidence for a mid $20^{\text {th }}$ century age}

This time interval coincides with the 'Great Acceleration' in global economic activity following World War II (Steffen et al. 2007). The extraordinary growth of cities and megacities and major infrastructure projects (Fig. 4), and their associated deposits may be considered a distinctive feature of the Anthropocene (Zalasiewicz et al. 2014 a, Williams et al. 2013). This is perhaps the most apparent signature of anthropogenic impact in that today some $52.4 \%$ of the global population live in urban areas (United Nations Department of Economic \& Social Affairs 2012). This represents an increase from c. 7\% in 1800 . Despite their focus for human habitation, urban areas cover only about $1 \%$ of the ice-free land surface (Klein Goldewijk et al. 2010; Fig. 4). This coverage increases to about $91.9 \%$ in densely populated countries such as Japan (UNDESA 2012).

There has been a significant change in the nature and volume of physical artificial anthropogenic deposits from 1945 onwards (Fig. 2). The natural gradient of sediment transfer from high to low topographical areas has been overtaken by the anthropogenic flux of materials from resources extracted mainly from rural areas to deposition in urban areas in the form of construction schemes (Hooke 2000; Wilkinson 2005). There has been a dramatic rise in overburden and spoil ratios associated with mineral extraction and volumes of material worked and used for construction (Ford $\boldsymbol{e t}$ al. 2014). This is a response to increased demand through population growth and resource consumption and to technical innovations such as the rapid spread in use of bulldozers from the 1950's. Ford et al. (2014) argue that this time interval is characterised by electronic equipment, extensive concrete manufacture, deep mining and generation of vast amounts of waste. These stratigraphical signals are both sharp (to decadal level) and globally widespread.

Minerals such as mullite (present in fired brick and ceramics), ettringite, hillebrandite and portlandite (found in cement and concrete) are present in archaeological times, but have become significantly more common since the mid-20 ${ }^{\text {th }}$ century (Fig. 2) and are sufficiently stable to provide a lasting signature (Zalasiewicz et al. 2013). New metal alloys, mineraloid glasses, semiconductors, synthetic "minerals" and emerging nanomaterials may be uniquely indicative of the Anthropocene (Zalasiewicz et al. 2013). Plastics appeared in the environment in significant volumes since the mid 1940's, but by 
2008 an estimated 260 million tonnes of plastic was produced, increasing annually by $9 \%$ (Thompson et al. 2009). Much of this output finds its way to landfill or the sea, with microplastics becoming an abundant trace fossil within marine sediments since the 1950's (Barnosky 2013). However, uncertainty exists as to their persistence following burial or within the marine environment, though their decomposition would be associated

604

605

606

607

608

609

610

611

612

613

614

615

616

617

618

619

620

621

622

623

624

625

626

627 with release of toxic compounds which in themselves will result in a geochemical signature.

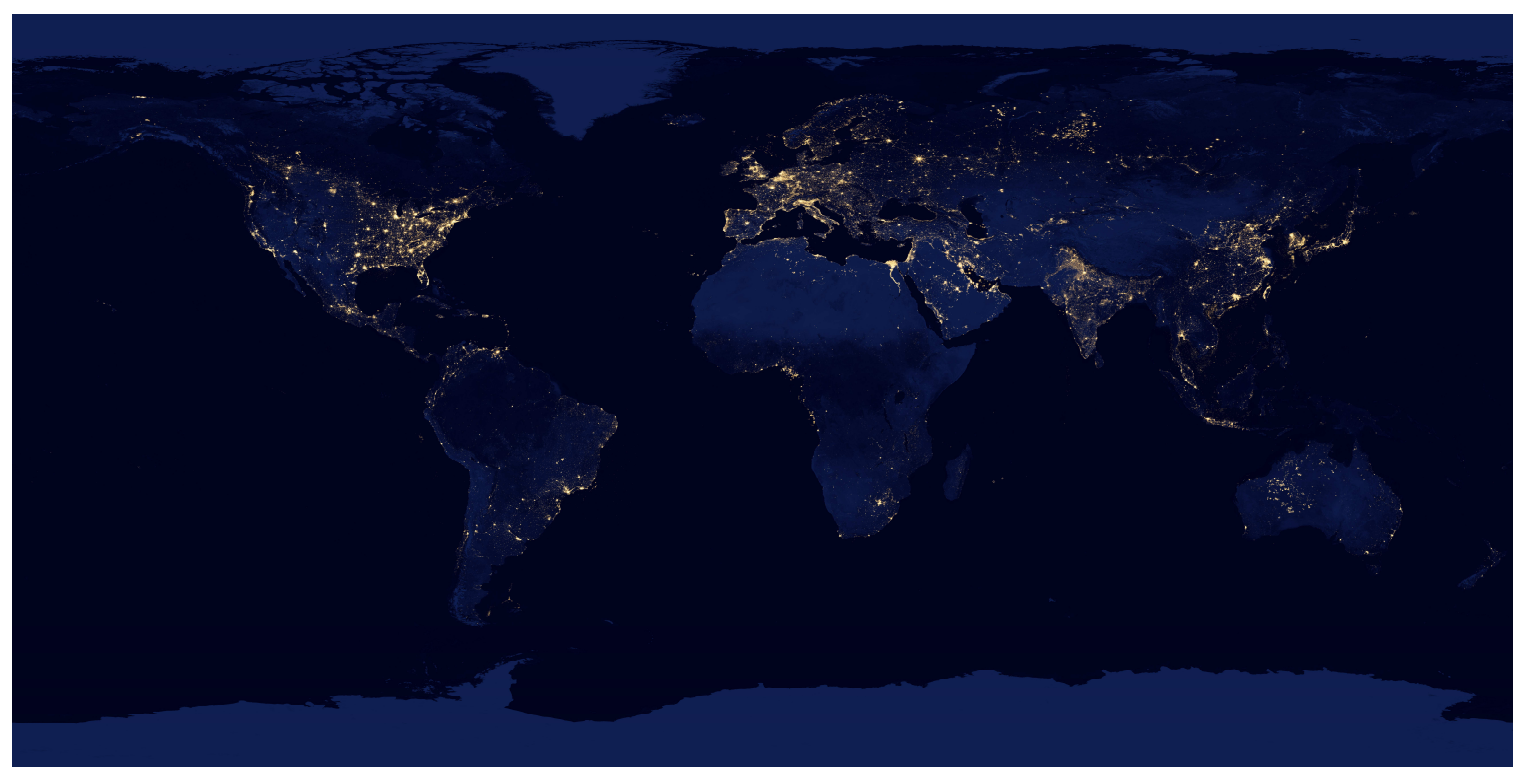

Fig. 4. View of the Earth at night, 2012, showing the distribution of urban conurbations, but not necessarily the most populated areas, through the presence of city lights. The image shows the domination of city construction in coastal areas, particularly in South America and Africa, and along major transport networks in North America, Europe, Russia, India and China. From Earth Observatory, NASA http://earthobservatory.nasa.gov/Features/NightLights/page3.php

Forests cover about $31 \%$ of the Earth's land surface (Food and Agricultural Organisation of the United Nations 2010), but as human populations increase, so too does the rate of deforestation. Since the 1950's, the scale of deforestation has increased by about $44 \%$ compared with the average for the past $5 \mathrm{kyr}$, with the net loss of forest of 5.2 million hectares over the first decade of the new millennium (FAO 2010). However, it is too early to see resultant increased mineral magnetic signatures as a consequence of deforestation since the mid 20th Century (Snowball et al. 2013). The areal extent of deforestation is now predominantly in tropical forests, in part due to demand for the timber, but also the clearance of forests for agricultural development and fuel supply (FAO 2010). Erosion of soils have undoubtedly increased as a result of this deforestation, (e.g. Dearing \& Jones 2003 and references therein) and has resulted in increased sediment input to fluvial systems. In contrast, the role of agriculture on the unintentional erosion of soils is considered to have declined dramatically since the 1950's in response to modern soil conservation practices in developed countries (Hooke 2000). Since the 1940 's there has been an increase in direct management of rivers, such as construction of 
dams, channel maintenance and urbanisation of floodplains (Merritts et al. 2011, Syvitski \& Kettner 2011). The proliferation in building of major dam schemes across the globe (Syvitski \& Kettner 2011) has caused about $20 \%$ of sediment load to be retained by reservoirs (Syvitski et al. 2005). As a result global river systems typically show a peak flux of sediments to the oceans by the early $20^{\text {th }}$ century (Syvitski \& Kettner 2011). Many coastal deltas have seen net subsidence since the 1930's, partly in response to this reduced sediment influx from the rivers, but also the impact of water and hydrocarbon extraction from deltas (Syvitski \& Kettner 2011). Increased development of urban areas on deltas results in greater loading and compaction. Sediment flux is further reduced as a result of the construction of flood-prevention schemes designed to prevent sediment recharge of the inhabited parts of the delta top.

Traditional biostratigraphical signatures, used elsewhere in the stratigraphical column, may continue to have applicability to the definition of the Anthropocene. Although the introduction of exotic species are first documented following the onset of the Industrial Revolution in parts of the globe (Fig. 3), there has been accelerated introductions during increased global transportation during World War II and the subsequently in the 1970's with the introduction of supertankers (Barnosky 2013; Fig. 2). The release of ballast waters is now the main route of transporting invasive species, particularly with colonisation within estuaries near to port facilities (Roberts 2012). It is perhaps in the controlled evolution of crops that most precise biostratigraphical tools may be found. Lineage zones based upon maize hybrids may be suitable as the crop is geographically widespread, can only reproduce through human cultivation and may be preserved in sediments for thousands of years (Barnosky 2013). Morphologically distinct and widespread hybrids have been developed in the 1840's and 1930's, though if molecular biology techniques are considered mutations $\sim 1950$ and genetically modified variants marketed since 1998 may also be recognised (Barnosky 2013).

Microfaunal and microfloral signatures within the marine environment are the most widely used biostratigraphical tool in the Phanerozoic and signatures can also be recognised which may help resolve the definition of the Anthropocene. Potential drivers include increasing nutrient loading ( $\mathrm{N}$ and $\mathrm{P}$ ) and eutrophication, acidification, presence of inorganic pollutants, alkalisation and climate change. In the Arctic and alpine lakes there is evidence of diatom assemblage responses indicative of eutrophication coinciding with increasing atmospheric $\mathrm{N}$ deposition since about 1950-1970 and after 1980 (Wolfe et al. 2013, Wilkinson et al. 2014). Benthic Foraminifera are sensitive to eutrophication, heavy metal and organic pollutants, changes in water management practices, introduction of non-indigenous species and land use changes. Foraminiferal records show a dramatic increase in the frequency and intensity of bottom-water hypoxia events since the mid- $20^{\text {th }}$ century, coinciding with the increased use of $\mathrm{N}$ - and P-based fertilisers (Blackwelder et al. 1996, Wilkinson et al. 2014). Ostracod abundance and diversity is related to eutrophication in freshwater and marginal marine settings, industrial pollution, sewage effluents, oil pollution, fish farming and salinity variations and a marked reduction in diversity has become more widespread and profound during the mid $20^{\text {th }}$ century (Wilkinson et al. 2014). 
674 During the latter half of the $20^{\text {th }}$ century fish stocks have fallen dramatically. This is in 675 part the consequence of overfishing due to the increasing use of factory fleets using 676 improved technologies such as echo location and satellite data and increasingly larger ships, drift nets and longlines (Roberts 2012). But, increasing artisanal fishing in coastal areas is also an important factor. The consequence is likely to be evident in sediments as reduced numbers and diversity of fish remains. In coastal and marine shelf/slope settings down to $\sim 1 \mathrm{~km}$ depth this biostratigraphical signature would coincide with extensive anthropogenic modification of surface sediments (Puig et al. 2012, Roberts 2012) with bottom trawling and dredging affecting 15 million $\mathrm{km}^{2} / \mathrm{a}$, about half the area of global continental shelves (Watling \& Norse 1998). Contrast this with the early $19^{\text {th }}$ century when only about $1 \%$ of the oceans were exploited (Roberts 2012). The effect may be most apparent in deep oceans where fish have low reproductive rates and stocks are largely unprotected from overfishing. Other pressures, such as the increased introduction of fish-farming in estuaries may also influence fish stocks through transmission of disease and introduction of nutrients and pollution from antibiotics, pesticides and fungicides (Roberts 2012). The massive growth of jellyfish populations, formerly in part controlled by a healthy fish population, can also threaten fish numbers through competition and consumption of fish eggs (Roberts 2012).

Coral reefs extend over only $0.1-0.2 \%$ of the oceans and are less extensive than the urbanised zones are on land. Despite being of limited areal extent, modern reefs account for a significant component of marine biotic diversity. Pollution, warming and acidification of ocean waters, eutrophication, and reduction of light levels due to increased sediment flux as coastal forests were removed, have seriously stressed coral reefs (Hoegh-Guldberg 2014). The frequency and severity of mass coral bleaching episodes, beginning in 1979, have increased with time (Hoegh-Guldberg 2014). There has been a $50 \%$ reduction in the abundance of reef-building corals over the past 40-50 years (Fig. 2), with rates of change several orders of magnitude higher than for much of the last million years (Hoegh-Guldberg 2014). The effects of oceanic acidification is still, however, uncertain. Upper ocean $\mathrm{pH}$ across open oceans to coastal waters at various latitudes is highly site-dependent with $\mathrm{pH}$ values that range markedly (0.024 to 1.43 units) on a monthly basis (Hofmann et al. 2011). Even within the comparatively stable open oceans, episodic variations in $\mathrm{pH}$ are greater than the annual rate of acidification, meaning that the influence of ocean acidification on oceanic biota is unlikely to be simple to predict in detail (Hofmann et al. 2011) and some organisms will be more sensitive to $\mathrm{pH}$ change than others. However, as the entire range of $\mathrm{pH}$ variation will be shifted to lower values by anthropogenic $\mathrm{CO} 2$ emissions, significant consequences are likely.

Anthropogenic production of carbon, nitrogen and phosphorus from activities such as fossil fuel combustion, agriculture and fertilizer production increased (Fig. 2), both in volume of output and spatial reach during the mid $20^{\text {th }}$ century (Gałuszka et al. 2013). One of the more significant signatures over the past century has been a doubling of reactive nitrogen at the Earth's surface, particularly in response to the invention and implementation of the Haber process from 1913 (Zalasiewicz et al. 2011).. Influx of excess reactive nitrogen to the ocean has resulted in increased eutrophication, increasing algal blooms and in turn causing oxygen deficiency changing the redox potential, with 
this process intensifying over the last 30 years (Gałuszka et al. 2013). Remote northern hemisphere lakes show depletion in $\delta^{15} \mathrm{~N}$ values (Holtgrieve et al. 2011, Wolfe et al. 2013) starting at $1895 \mathrm{CE} \pm 10$ years, but accelerating over the past 50 years (Fischer $e t$ al. 1998). In Greenland ice, the main phase of increase was 1950-1980, culminating in levels higher than observed for the previous $100 \mathrm{kyr}$ (Wolff 2013; Fig. 2), representing a marker that is distinct from the Holocene background.

Sulphate concentrations in Greenland ice rose by a factor of 4 over pre-industrial levels with the main increases between 1900-1920 CE and 1940-1980 CE (Wolff 2013). Atmospheric disturbance of the sulphur cycle is also evident in both speleothems and trees (Fairchild \& Frisia 2013). However, the increases in sulphate concentration fall within ranges possible from both large volcanic eruptions (Smith et al. 2013) and associated with the last glacial maximum, suggesting this is not a suitable primary marker for the Anthropocene.

Industrially-produced metal pollutants including $\mathrm{Pb}, \mathrm{Cd}, \mathrm{Cu}, \mathrm{Zn}$, can undergo long-range atmospheric transport, commonly occur at levels above natural background across many depositional environments and are likely to persist in the future geological record (Gałuszka et al. 2013). Stable lead isotopes are particularly important for recognising the global pollutant signature associated with alkylead additives in gasoline as an antiknocking agent from 1940-1980 (Gałuszka $\boldsymbol{e t}$ al. 2013). Lead concentrations in Greenland snow in 1960 were a factor of 200 above the Holocene background level (Boutron et al. 1991, Wolff 2013). Emerging pollutants that are uniquely associated with modern technological advances may represent an important signature for the Anthropocene. Rare earth elements, used in modern high-technology industries and medicine, are now appearing in the environment and are very persistent and nonbiodegradable (Gałuszka et al. 2013). Persistent organic pollutants (POP) also provide potential signatures because of their long residence time in different environments and resistance to degradation, but these would still not represent long-term signatures when viewing the start of the Anthropocene several thousands of years hence.

Temporal trends in accumulation of pollutants in sediments will differ regionally, dependent upon the diachronous expansion of industrialization (Fig.3). Signatures may also be affected by changes in $\mathrm{pH}$ and redox potential of sediments, which may result in remobilization of substances (Gałuszka et al. 2013). Ultimately, the diachroneity in many geochemical anthropogenic signals may limit their use for defining the base of the Anthropocene. However, the most dramatic isochronous contamination signature of the mid $20^{\text {th }}$ Century is the beginning of the nuclear age and the global spread of artificial radionuclides. Global scale enrichment in artificial radioisotopes has resulted from atmospheric nuclear weapon testing, mainly from 1945-1980 (Fig. 2), with more localised though still widespread signatures associated with discharges from nuclear reactors (Hancock et al. 2013, Gałuszka et al. 2013). There is a ${ }^{137}$ Cs fallout peak of 1963-64 (mainly in northern hemisphere sediments) and a more globally extensive peak in 1964 for ${ }^{239} \mathrm{Pu}$. Ice cores show jumps in beta-radioactivity in 1954 and 1964 with a peak in 1966 a factor of 100 above background levels (Wolff 2013). Speleothems record a widespread and unambiguous radiocarbon signal that commenced in 1955 and peaked 
in 1962, relating to atmospheric nuclear testing. Following the test-ban treaty levels of ${ }^{14} \mathrm{C}$ in the atmosphere has declined exponentially (Fairchild \& Frisia 2013). This signature has been recorded in corals and salt marshes. However, it is probably the initial post-1945 rise in concentrations that would be used to mark a putative base of the Anthropocene, rather than the peak signature.

Given the weight of evidence, including some of the issues described above, Zalasiewicz et al. (2014 a) argue the case for a $\sim 1950$ CE date for the onset of the Anthropocene.

\section{Future perspective}

There is a strong argument, forwarded by Wolff (2013) that the characteristics of the fully-developed Anthropocene are still uncertain and that we may be living through a transition towards a new epoch, rather than being fully within it. With the exception of the definition of the Holocene, decisions made to ratify chronostratigraphical units have been made with the understanding that the events or signatures characteristic of that time period have finished. This is not true for the Anthropocene, but the erection of a new Anthropocene Epoch can only be made on the basis of material evidence of elapsed events. Projections of future trends are simply predictions: some are more robustly founded than others and they can provide a sense of perspective when considering recent patterns. Ultimately, if there is a consensus that the main environmental changes lie ahead of us, it might be concluded that it is too early to judge the position of the base of the Anthropocene, even if there is sufficient material evidence (including that detailed in this volume) that the stratigraphic change to date is significant.

Each of the various events that have been proposed or discussed here as starting points for an Anthropocene epoch is diachronous and spatially heterogeneous. But, the level of diachroneity varies from several millennia (e.g. urbanization) to a very few years (e.g. artificial radionuclide deposition). Virtually all stratigraphic boundaries are diachronous and spatially heterogenous to an extent that would make any of the potential Anthropocene bounding events seem effectively instantaneous, in a far-future perspective. The key question here is whether the range of evidence currently existing can enable contemporary Earth scientists to effectively and usefully demarcate and correlate the Anthropocene as a stratigraphic unit.

There is also concern, rightly so, for the potential for preservation of an Anthropocene bounding event (e.g. Ford et al. 2014). The traces of existing bounding events for deeptime stratigraphic boundaries are, of course, not universally preserved. Preservation depends on many factors, but it can be reasonably predicted, say, that cities sited on subsiding deltas are much more likely to enter the stratigraphic record in some form than those sited in mountainous terrain. Ice core from Greenland has been used to define a GSSP for the Pleistocene/Holocene boundary (Walker et al. 2009) and has the potential to also be used for the Anthropocene (e.g. Smith 2013, Wolff 2013). However, with extensive wasting of ice within a realm of increasing global temperatures, with greatest increases in polar regions, the likely preservation of ice formed a little over half a century ago is uncertain. 
812 Despite the imposition of anthropogenically-induced environmental stresses on global

813 flora and fauna over recent centuries and decades, there is presently no justification for 814 associating a mass extinction horizon with this time interval (Barnosky et al. 2011, 815 Barnosky 2013). However, if currently elevated extinction rates continue, the sixth mass 816 extinction (75\% species loss) would occur within three to five centuries and that an 817 extinction threshold exceeding the late Quaternary Megafaunal Extinction could occur 818 even sooner (Barnosky 2013). Probably the single most significant extinction event of a 819 single species would be that of mankind itself, but could not be used to justify the

856 Global estimates of sea-level rise in response to thermal expansion and melting of land857 based ice for the $20^{\text {th }}$ and $21^{\text {st }}$ centuries are ca. $1.8 \mathrm{~mm} \mathrm{a}^{-1}$ (Church \& White 2011), 
considered an acceleration on previous centuries. Precise determinations using satellite altimetry indicate rates of sea-level rise of 3.2 $\pm 0.4 \mathrm{~mm} \mathrm{a}^{-1}$ from 1993-2009 (Church \& 860 White 2011), which suggests a continuation of this acceleration. This should be compared with the $>40 \mathrm{~mm} \mathrm{yr}^{-1}$ during the last deglaciation ca. $14 \mathrm{ka}$ BP (Fairbanks 1989). Modelling limits predictions to 2100 , and estimates for subsequent increased rates in sealevel elevation are difficult to quantify, but the extreme estimate would be melting of all ice-sheets leading to a sea-level rise of $80 \mathrm{~m}$ (Williams \& Hall 1993). By comparison with the Cretaceous and Eocene 'greenhouse intervals' it is expected that with a doubling of $\mathrm{CO}_{2}$ from pre-Industrial levels there will be an increase in the precipitation rate (Haywood et al. 2011), which would be expected to cause both increased soil erosion and increased discharges in fluvial systems.

Increased output of anthropogenic $\mathrm{CO}_{2}$ may result in future acidification of the oceans and significant under-saturation of $\mathrm{CaCO}_{3}$. This may cause a shallowing in average carbonate compensation depth and production of a prolonged carbonate gap (for several thousand years) in deep marine deposits, such that paler coccolith and foraminifer oozes will become rare and darker clay and silicic deposits dominate (Tyrell 2011).

Haff (2013) suggests an alternative view of the Anthropocene as an age of technology, with increasing domination of our environment by an emergent technosphere, of which humans are components. Haff ( op cit.) suggests that the technosphere has evolved into a dynamic system, but as a juvenile system that has not reached equilibrium, being a poor recycler of critical resources. Appropriation of energy by the technosphere has resulted in disruption to the lithosphere, atmosphere, hydrosphere and biosphere. Time will tell if this event is like the Great Oxidation Event about 2.4 Billion years ago, that resulted in a shift in the global state. Or, if unsustainable, the evolution and demise of the technosphere represents a brief episode, comparable to the K-T impact event.

\section{Summary and conclusions}

In summary, it is recognised that in order to define the Anthropocene as a formal chronostratigraphical unit, it is necessary to apply the same rigorous evidence-based approach to recognising key signatures as has been used for the definition of older units. However, there should be concerns if special criteria are being imposed to justify the definition that could not be met by these older units.

Ultimately, there is a requirement to identify a critical change to a new regime in which anthropogenic influence is a dominant controlling factor upon aspects as diverse as biotic abundance and variability, sediment flux and sediment composition, geochemical and radiogenic signatures, climate change, sea-level rise, ice-cover loss etc. Ideally, the definition of the Anthropocene should be based upon a single, globally-expressed signature. This could be, for example the appearance of radiogenic fallout, though there remains the questions as to whether the initial post-1945 rise or the peak signature some two decades later be used. However, definition drawing upon a spectrum of signatures would enable characterization of the unit to reflect a profound change across many environmental indicators. As demonstrated in this contribution, the onset of the broad range of signatures is diachronous, spanning almost $11 \mathrm{kyr}$ or more (Fig. 2). Many, 
904 though not all, of the indicators covered in this special publication show maximum 905 signatures which post-date 1945 leading to the suggestion that this date may be a suitable 906 age for the commencement of the Anthropocene should it prove useful and necessary to define it (Fig. 2). What cannot be quantified is the extent that the acme of many of these signatures lies ahead in the future, indicating that we lack the full perspective of geological time to review the total impact of humans on Earth. It is important to recognise that human decision-making has the potential to shape the future geological record. For the present, we must continue to work with a developing narrative, even as it unfolds.

The authors wish to acknowledge the helpful comments from Simon Price and Vanessa Banks and constructive feedback from Daniela Schmidt is also gratefully acknowledged. Figure 1 was designed by Chris Wardle. This article is published with the permission of the Executive Director of the British Geological Survey (NERC).

\section{References}

AGER, D.V. 1993. The nature of the Stratigraphical record (Third edition). John Wiley \& Sons.

AKÇAR, N., Ivy-Ochs, S. \& Schlüchter, C. 2008. Application of in-situ produced terrestrial cosmogenic nuclides to archaeology: A schematic review. Eiszeitalter und Gegenwart Quaternary Science Journal, 57, 226-238.

BARNoSKy, A.D. 2013. Palaeontological evidence for defining the Anthropocene. In: Waters, C.N., Zalasiewicz, J., Williams, M., Ellis, M.A. \& Snelling, A. (Eds) A Stratigraphical Basis for the Anthropocene. Geological Society, London, Special Publications, 395, doi:10.1144/SP395.6.

Barnosky, A.D., Matzke, N., Tomiya, S., Wogan, G.O.U., Swartz, B., Quental, T.B., Marshall, C., McGuire, J.L., Lindsey, E.L., Maguire, K.C., Mersey, B. \& FERRER, E.A. 2011. Has the Earth/'s sixth mass extinction already arrived? Nature, 471, $51-57$.

Battarbee, R.W., Morley, D., Bennion, H., Simpson, G.L., Hughes, M. \& Bauere, V. 2011. A palaeolimnological meta-database for assessing the ecological status if lakes. Journal of Paleolimnology, 45, 405-414.

Blackwelder, P., Hood, T., Alvarez-Zarikian, C., Nelsen, T.A. \& McKee, B. 1996. Benthic Foraminifera from the NECOP study area impacted by the Mississippi River plume and seasonal hypoxia. Quaternary International, 31, 19-36.

Boutron, C. F., Görlach, U., Candelone, J.-P., Bolshov, M. A. \& Delmas, R. J. 1991. Decrease in anthropogenic lead, cadmium and zinc in Greenland snows since the late 1960s. Nature, 353, 153-156. 
950 BRADlEY, R.S. 1999. Paleoclimatology: Reconstructing Climates of the Quaternary. 951 Harcourt Academic Press. pp.613.

952

Briffa, K.R., Jones, P.D., SchweIngRUber, F.H., Osborn, T.J., 1998. Influence of volcanic eruptions on Northern Hemisphere summer temperature over the past 600 years.

Brown, A., Toms, P., CArey, C. \& Rhodes, E. 2013. Geomorphology of the Anthropocene: Time-transgressive discontinuities of human-induced alluviation.

988 EdgewORTH, M. 2013. Archaeological stratigraphy and artificial ground. In: WATERS,

993 ELERT, G. The Physics Hypertextbook. http://physics.info/half-life/ , accessed 2013994 09-18. 
Ellis, E.C., Antill, E.C. \& KReft, H. 2012. All Is Not Loss: Plant Biodiversity in the

Anthropocene. PLoS ONE, 7, e30535, doi: 10.1371/journal.pone.0030535.

Ellis, E.C., Kaplan, J.O., Fuller, D.Q., Vavrus, S., Klein GoldewiJK, K. \& VERBURG, P.H. 2013. Used planet: A global history. Proceedings of the National

1002

1003

1004 Academy of Sciences, 110, 7978-7985, doi: 10.1073/pnas.1217241110.

FAIRCHILD, I.J. \& FRISIA, S. 2013. Definition of the Anthropocene: a view from the underworld. In: Waters, C.N., Zalasiewicz, J., Williams, M., Ellis, M.A. \& SNelling, A. (Eds) A Stratigraphical Basis for the Anthropocene. Geological Society, London, Special Publications, 395, doi:10.1144/SP395.7.

FAIRBANKS, R.G. 1989. A 17,000-year glacio-eustatic sea-level record: Influence of glacial melting rates on the Younger Dryas event and deep-ocean circulation. Nature, $342,637-642$.

Food And Agriculture Organization of the United Nations (FAO) 2010. Global Forest Resources Assessment 2010 - main report. FAO Forestry Paper No. 163. Rome. www.fao.org/docrep/013/i1757e/i1757e00.htm.

FINNEY, S. C. 2013. The 'Anthropocene' as a ratified unit in the ICS International Chronostratigraphic Chart: fundamental issues that must be addressed by the Task Group. In: Waters, C.N., Zalasiewicz, J., Williams, M., Ellis, M.A. \& Snelling, A. (Eds) A Stratigraphical Basis for the Anthropocene. Geological Society, London, Special Publications, 395, doi:10.1144/SP395.9.

Fischer, H., Wagenbach, D. \& Kipfstuhl, J. 1998. Sulfate and nitrate firn concentrations on the Greenland ice sheet. 2. Temporal anthropogenic deposition changes. Journal of Geophysical Research, 103, 21935-21942.

Ford, J.R., Price, S.J., COOPER, A.H. \& WATERS, C.N. 2014. An assessment of lithostratigraphy for anthropogenic deposits. In: WATERS, C.N., ZALASIEWICZ, J., Williams, M., Ellis, M.A. \& Snelling, A. (Eds) A Stratigraphical Basis for the Anthropocene. Geological Society, London, Special Publications, 395,***.

Gale, S.J. \& Hoare, P.G. 2012. The stratigraphic status of the Anthropocene. The Holocene, 22, 1478-1481.

1040

GaŁuszKa, A., Migaszewski, Z.M. \& ZalasiewicZ, J. 2013. Assessing the Anthropocene with geochemical methods. In: WATERS, C.N., ZALASIEWICZ, J., Williams, M., Ellis, M.A. \& Snelling, A. (Eds) A Stratigraphical Basis for the Anthropocene. Geological Society, London, Special Publications, 395, doi:10.1144/SP395.5. 
1041 GibBaRd P.L., HEAD, M.J., WalKer, M.J.C, 2010. Formal ratification of the Quaternary 1042 System/Period and the Pleistocene Series/Epoch with a base at 2.58 Ma. Journal of 1043 Quaternary Science, 25 (2), 96-102.

1044

1045

1046

1047

1048

1049

1050

1051

1052

1053

1054

1055

1056

1057

1058

1059

1060

1061

1062

1063

1064

1065

1066

1067

1068

1069

1070

1071

1072

1073

1074

1075

1076

1077

1078

1079

1080

1081

1082

1083

1084

1085

1086

1087

GibBard, P.L. \& WALKer, M.J.C. 2013. The term 'Anthropocene' in the context of formal geological classification. In: Waters, C.N., ZaLASIEWICZ, J., WiLliams, M., Ellis, M.A. \& Snelling, A. (Eds) A Stratigraphical Basis for the Anthropocene. Geological Society, London, Special Publications, 395, doi:10.1144/SP395.1.

Gosse, J.C. \& PhILLIPS, F.M. 2001. Terrestrial in situ cosmogenic nuclides: Theory and application. Quaternary Science Reviews, 20, 1475-1560.

Gradstein, F.M., OgG, J.G., Schmitz, M. \& OGG, G. 2012. The Geological Time Scale 2012. No. 2 Volumes. (Elsevier.) ISBN 978-0-444-59425-9.

HAFF, P. 2013. Technology as a geological phenomenon: Implications for human wellbeing. In: Waters, C.N., Zalasiewicz, J., Williams, M., Ellis, M.A. \& SNELling, A. (Eds) A Stratigraphical Basis for the Anthropocene. Geological Society, London, Special Publications, 395, doi:10.1144/SP395.4.

Hancock, G.J., Tims, S.G., Fifield, L. K. \& Webster, I.T. 2013. The Release and Persistence of Radioactive Anthropogenic Nuclides. In: WATERS, C.N., ZALASIEWICZ, J., Williams, M., Ellis, M.A. \& Snelling, A. (Eds) A Stratigraphical Basis for the Anthropocene. Geological Society, London, Special Publications, 395,***.

Haywood, A.M., Ridgewell, A., Lunt, D.J., Hill, D.J., Pound, M.J., DowseTt, H.J., Dolan, A.M., FRANCIS, J.E. \& WILLIAMS, M. 2011. Are there pre-Quaternary geological analogues for a future greenhouse warming? Philosophical Transactions of the Royal Society, London, Series A, 369, 933-956.

HedBerg, H.D. (ed.) 1976. International Stratigraphic Guide--A Guide to Stratigraphic Classification, Terminology, and Procedure. New York, John Wiley \& Sons, 200 p.

HoEgh-GuldBerG, O. 2014. Coral reefs in the Anthropocene: persistence or the end of the line? In: Waters, C.N., Zalasiewicz, J., Williams, M., Ellis, M.A. \& SNelling, A. (Eds) A Stratigraphical Basis for the Anthropocene. Geological Society, London, Special Publications, 395, $* * *$.

Hofmann, G.E., Smith, J.E., Johnson, K.S., Send, U., Levin, L.A., Micheli, F., Paytan, A., Price, N.N., Peterson, B., Takeshita, Y., Matson, P.G., Crook, E.D., Kroeker, K.J., Gambi, M.C., Rivest, E.B., Frieder, C.A., Yu, P.C. \& Martz, T.R. 2011. HighFrequency Dynamics of Ocean pH: A Multi-Ecosystem Comparison. PLoS ONE, Vol. 6, e28983.

Holtgrieve, G.W., Schindler, D.E., Hobbs, W.O., Leavitt, P.R., Ward, E.J., Bunting, L., Chen, G., Finney, B.P., Gregory-Eaves, I., Holmgren, S., Lisac, M.J., Lisi, P.J., Nydick, K., Rogers, L.A., Saros, J.E., Selbie, D.T., Shapley, M.D., Walsh, P.B. \& 
Wolfe, A.P. 2011. A Coherent Signature of Anthropogenic Nitrogen Deposition to Remote Watersheds of the Northern Hemisphere. Science, 334, 1545-1548. Hooke, R. LeB. 2000. On the history of humans as geomorphic agents. Geology, 28, 843846.

KLEIN GOLDEWIJK K., BEUSEN A. \& JANSSEN P. 2010. Long-term dynamic modeling of global population and built-up area in a spatially explicit way: HYDE 3.1. Holocene, 20(4), 565-573.

Leinfelder, R.R., Seemann, J., Heiss, G.A. \& Struck, U. 2012. Could 'Ecosystem Atavisms' Help Reefs to Adapt to the Anthropocene? Proceedings of the 12th International Coral Reef Symposium, Cairns, Australia, 9-13 July 2012. Online publication http://www.reefbase.org/resource_center/publication/icrs.aspx.

LisIECKI, L.E. \& RAYMO, M.E., 2005. A Pliocene-Pleistocene stack of 57 globally distributed benthic $\delta^{18} \mathrm{O}$ records. Paleoceanography, 20 (1), PA1003. doi:10.1029/2004PA001071.

LOCKE, G. \& BERTINE, K.K. 1986. Magnetic sediments as an indicator of coal combustion. Applied Geochemistry, 1, 345-356.

Loulergue, L., Schilt, A., Spahni, R., Masson-Delmotte, V., Blunier, T., LemieuX, B., Barnola, J. M., RAynaud, D., Stocker, T. F. \& Chappellaz, J. 2008. Orbital and millennial-scale features of atmospheric $\mathrm{CH}_{4}$ over the last 800,000 years. Nature, 453, 383-386.

LÜTHI, D., Le Floch, M., STOCKer, T. F., Bereiter, B., Blunier, T., BARnOla, J. M., Siegenthaler, U., Raynaud, D. \& JouZEL, J. 2008. High-resolution carbon dioxide concentration record 650,000-800,000 years before present. Nature, 453, 379-382.

Merritts, D., Walter, R., Rahnis, M., Hartranft, J., Cox, S., Gellis, A., Potter, N., Hilgartner, W., Langland, M., Manion, L., Lippincott, C., Siddiqui, S., Rehman, Z., Scheid, C., Kratz, L., Shilling, A., Jenschke, M., Datin, K., Cranmer, E., Reed, A., Matuszewski, D., Voli, M., Ohlson, E., Neugebauer, A., Ahamed, A., NEAL, C., WinTER, A. \& BECKER, S. 2011. Anthropocene streams and base-level controls from historic dams in the unglaciated mid-Atlantic region, USA. Philosophical Transactions of the Royal Society, Series A, 369, 976-1009.

Poirier, C., Chaumillon, E. \& ARnaud, F. 2011. Siltation of river-influenced coastal environments: Respective impact of late Holocene land use and high-frequency climate changes. Marine Geology, 290, 51-62, doi: 10.1016/j.margeo.2011.10.008.

PRICE, S.J., ForD, J.R., COOPER, A.H. \& NEAL, C. 2011. Humans as major geological and geomorphological agents in the Anthropocene: the significance of artificial ground in 
1133 Great Britain. Philosophical Transactions of the Royal Society, A2011 369, 1056-1084, 1134 doi: 10.1098/rsta.2010.0296.

1135

1136

1137

1138

1139

1140

1141

1142

1143

1144

1145

1146

1147

1148

1149

1150

1151

1152

1153

1154

1155

1156

1157

1158

1159

1160

1161

1162

1163

1164

1165

1166

1167

1168

1169

1170

1171

1172

1173

1174

1175

1176

1177

1178
Puig, P., Canals, M., Company, J.B., Martin, J., Amblas, D., Lastras, G., PalanQues, A. \& CAlafat, A.M. 2012. Ploughing the deep sea floor. Nature, 489, 286289.

REVKIN, A. 1992. Global warming: understanding the forecast. American Museum of Natural History, Environmental Defense Fund, Abbeville Press.

ROBERTS, C. 2012. Ocean of Life: How our seas are changing. Allen Lane, 400pp.

RiChTER, D. DEB. 2007. Humanity's transformation of Earth's soil: Pedology's new frontier. Soil Science, 172 (12), 957-967.

RudDiman, W.F. 2003. The Anthropogenic Greenhouse Era began thousands of Years Ago. Climatic Change, 61, 261-293.

Ruddiman, W.F. 2005. Plows, Plagues and Petroleum. Princeton University Press: Princeton NJ.

Salvador, A., 1994. International Stratigraphic Guide. A guide to stratigraphic classification, terminology, and procedure $2^{\text {nd }}$ Edition. The International Union of Geological Sciences and The Geological Society of America (Colorado).

Scheibner, C, \& SpeIJer, R P. 2008. Decline of coral reefs during late Paleocene to early Eocene global warming. eEarth, 3, 19-26.

Schilt, A., Baumgartner, M., Blunier, T., Schwander, J., Spahni, R., Fischer, H. \& STOCKER, T. F. 2010. Glacial-interglacial and millennial-scale variations in the atmospheric nitrous oxide concentration during the last 800,000 years. Quaternary Science Reviews, 29, 182-192, doi: 10.1016/j.quascirev.2009.03.011.

SHACKLETON, N.J. \& OPDYKE, N.D., 1973. Oxygen isotope and palaeomagnetic stratigraphy of the equatorial Pacific core V28-238: Oxygen isotope temperatures and ice volumes on a 105 and 106 year scale. Quaternary Research, 3, 39-55. http://dx.doi.org/10.1016/0033-5894(73)90052-5.

Shen, S.-Z., Henderson, C.M., Bowring, S.A., CaU, C.-Q., Wang, Y., Wang, W., ZhANG, H., ZhANG, Y.-C. \& Mu, L., 2010. High-resolution Lopingian (Late Permian) timescale of South China. Geological Journal, 45, 122-134.

SiMPSON, I.A. 1997. Relict properties of anthropogenic deep top soils as indicators of infield management in Marwick, West Mainland, Orkney. Journal of Archaeological Science, 24 (4), 365-380. 
Singarayer, J.S., Valdes, P.J., Friedlingstein, P., Nelson, S. \& Beerling, D.J. 2011. Late Holocene methane rise caused by orbitally controlled increase in tropical sources. Nature, 470, 82-86.

Smith, A.G., Barry, T., Bown, P., Cope, J., Gale, A., Gibbard, P., Gregory, J., WATERS, C. 2014. GSSPs, global stratigraphy and correlation. In: Strata and Time: Probing the Gaps in Our Understanding (Ed. Smith, D). Proceedings of the William Smith meeting, ***.

Smith, V. C. 2013. Defining the onset of the Anthropocene using tephrochronology. In: Waters, C.N., Zalasiewicz, J., Williams, M., Ellis, M.A. \& Snelling, A. (Eds) A Stratigraphical Basis for the Anthropocene. Geological Society, London, Special Publications, 395, doi:10.1144/SP395.11.

Snowball, I., Hounslow, M.W. \& Nilsson, A. 2013. Geomagnetic and mineral magnetic characterisation of the Anthropocene. In: Waters, C.N., ZaLASIEWICZ, J., Williams, M., Ellis, M.A. \& Snelling, A. (Eds) A Stratigraphical Basis for the Anthropocene. Geological Society, London, Special Publications, 395, doi:10.1144/SP395.13.

Solomon, S. Qin, D., Manning M., Chen, Z., Marquis, M., Averyt, K.B. Tignor M. \& Miller H.L. (eds.) 2007. Contribution of Working Group I to the Fourth Assessment Report of the Intergovernmental Panel on Climate Change, 2007. (Cambridge University Press, Cambridge \& New York).

Steffen, W., Sanderson, A., Tyson, P.D., Jaeger, J., Matson, P.A., Moore, B., Oldfield, F., Richardson, K., SCHNEllnhuber, H.J., TuRner, B.L. \& WASSON, R.J., 2004. Global Change and the Earth System: A Planet under Pressure. Berlin, SpringerVerlag.

StefFen, W., CRUTZEn, P.J. \& MCNEILL, J.R., 2007, The Anthropocene: are humans now overwhelming the great forces of Nature? Ambio, 36, 614-621.

StopPani, A.1873. Corsa di Geologia. Milan, Bernardoni \& Brigola.

Stuiver, M. \& Polach, H.A. 1977. Discussion: Reporting of ${ }^{14}$ C data. Radiocarbon, 19, 355-363.

Syvitski, J.P.M. \& KetTner, A. 2011. Sediment flux and the Anthropocene. Philosophical Transactions of the Royal Society, A369, 957-975.

Syvitski, J.P.M, Vörösmarty, C.J., KetTner, A.J., \& Green, P. 2005. Impact of Humans on the Flux of Terrestrial Sediment to the Global Coastal Ocean. Science, 308, 376-380. 
1225

1226

1227

1228

1229

1230

1231

1232

1233

1234

1235

1236

1237

1238

1239

1240

1241

1242

1243

1244

1245

1246

1247

1248

1249

1250

1251

1252

1253

1254

1255

1256

1257

1258

1259

1260

1261

1262

1263

1264

1265
Thompson, R.C., Moore, C.J., vom SaAl, F.S. \& Swan, S.H. 2009. Plastics, the environment and human health: current consensus and future trends Philosophical Transactions of the Royal Society, B364, 2153-2166, doi: 10.1098/rstb.2009.0053.

TyRrell, T. 2011. Anthropogenic modification of the oceans. Philosophical Transactions of the Royal Society, A369, 887-908.

UNDESA 2012. World Urbanisation Prospects, 2011 Revisions. United Nations Department of Economic and Social Affairs, New York.

http://hdrstats.undp.org/en/tables/displayByRow.cfm

UNTERWEGER, M.P. 2003. Radionuclide Half-Life Measurements of the National Institute of Standards and Technology (Version 3.0). [Online]. Available: http://physics.nist.gov/Halflife. Retrieved 18th September 2013. National Institute of Standards and Technology, Gainsburg, MD.

Walker, M., Johnsen, S., Olander Rasmussen, S., Popp, T., Steffense, J-P., Gibbard, P., Hoek, W., Lowe, J., Andrews, J., BJörck, S., Cwynar, L.C., Hughen, K., Newham, R. \& Schwander, J. 2009. Formal definition and dating of the GSSP (Global Stratotype Section and Point) for the base of the Holocene using the Greenland NGRIP ice core, and selected auxiliary records. Journal of Quaternary Science, 24, 3-17.

Walker, M.J.C., Berkelhammer, M., BJÖrck, S., CWynar, L.C., Fisher, D.A., Long, A.J., LOWE, J.J., NEWnhAM, R.M., RASMUSSEN, S.O. \& WEISS, H. 2012. Formal subdivision of the Holocene Series/Epoch: a Discussion Paper by a Working Group of INTIMATE (Integration of ice-core, marine and terrestrial records) and the Subcommission on Quaternary Stratigraphy (International Commission on Stratigraphy). Journal of Quaternary Science, 27, 649-659, doi: 10.1002/jqs.2565.

WAtLing, L. \& Norse, E.A. 1998. Disturbance of the Seabed by Mobile Fishing Gear: A Comparison to Forest Clearcutting. Conservation Biology, 12, 1180-1197, doi:

10.1046/j.1523-1739.1998.0120061180.x.

WiLKINSON, B.H. 2005. Humans as geologic agents: A deep-time perspective. Geology, 33, 161-164.

Wilkinson, I.P., Poirier, C., HeAD, M.J., SAYER, C.D. \& Tibby, J. 2014. Micropalaeontological signatures of the Anthropocene. In: WATERS, C. N., ZALASIEWICZ, J., Williams, M., Ellis, M. A. \& Snelling, A. (Eds) A Stratigraphical Basis for the Anthropocene. Geological Society, London, Special Publications, 395, ***. 
Williams, M., Zalasiewicz, J., Waters, C.N. \& LANDing, E. 2013. Is the fossil record of complex animal behaviour a stratigraphical analogue for the Anthropocene? In: Waters, C. N., Zalasiewicz, J., Williams, M., Ellis, M. A. \& Snelling, A. (Eds) A Stratigraphical Basis for the Anthropocene. Geological Society, London, Special

Williams, R.S. \& HALl, D.K. 1993. Glaciers. In: Gurney, R.J., Foster, J.L. \& Parkinson, C.L. (eds.) Atlas of Satellite observations related to global change. Cambridge University Press, Cambridge, U.K., 401-422.

Wolfe, A.P., Hobbs, W.O., Birks, H.H., Briner, J.P., Holmgren, S.U., Ingólfsson, Ó., Kaushal, S.S., Miller, G.H., Pagani, M., Saros, J.E. \& Vinebrooke, R.D. 2013. Stratigraphic expressions of the Holocene-Anthropocene transition revealed in sediments from remote lakes. Earth-Science Reviews, 116, 17-34.

WolfF, E.W. 2013. Ice Sheets and the Anthropocene. In: WATERS, C. N., ZALASIEwiCZ, J., Williams, M., Ellis, M. A. \& Snelling, A. (Eds) A Stratigraphical Basis for the Anthropocene. Geological Society, London, Special Publications, 395, doi:10.1144/SP395.10.

Woods, W.I. 2008. Amazonian Dark Earths: Wim Sombroek's vision (Springer, New York), pp. 504.

Yin, H., Zhang, K., Tong, J., Yang, Z. \& Wu, S., 2001. The Global Stratotype Section and Point (GSSP) of the Permian-Triassic boundary. Episodes, 24, 102-114.

Zalasiewicz, J., Williams, M., Smith, A., Barry, T.L., Coe, A.L., Bown, P.R., Brenchley, P., Cantrill, D., Gale, A., Gibbard, P., Gregory, F.J., Hounslow, M., Kerr, A.C., Pearson, P., Knox, R., Powell, J., Waters, C., Marshall, J., Oates, M., Rawson, P. \& Stone, P. 2008. Are we now living in the Anthropocene? Geological Society of America Today, 18, 4-8.

Zalaseiwicz, J., Williams, M., Fortey, R., Smith, A., Barry, T.L., Coe, A.L., Bown, P.R., Gale, A., Gibbard, P., Gregory, F.J., Hounslow, M.W., Kerr, A.C., Pearson, P., Knox, R., Powell, J., Waters, C., Marshall, J., Oates, M., Rawson, P., \& Stone, P. 2011. Stratigraphy of the Anthropocene. Philosophical Transactions of the Royal Society A, 369, 1036-1055.

Zalasiewicz, J., Williams, M. \& WATERS, C.N. 2014 a. Can an Anthropocene Series be defined and recognised? In: Waters, C. N., ZalasiewiCZ, J., Williams, M., Ellis, M. A. \& Snelling, A. (Eds) A Stratigraphical Basis for the Anthropocene. Geological Society, London, Special Publications, 395,***.

ZalasiewicZ, J., KRYZA, R. \& WiLliams, M. 2013 b. The mineral signature of the Anthropocene. In: Waters, C. N., ZalasiewicZ, J., Williams, M., Ellis, M. A. \& 
1311 Snelling, A. (Eds) A Stratigraphical Basis for the Anthropocene. Geological Society, 1312 London, Special Publications, 395, doi:10.1144/SP395.2.

1313

1314 Zalasiewicz, J., Williams, M., Waters, C.N., Barnosky, A.D. \& HafF, P. 2014 b. The 1315 technofossil record of humans. Anthropocene Review, 1, DOI: $131610.1177 / 2053019613514953$. 

proposed as an epoch by Crutzen \& Stoermer (2000) to denote the present time interval, in which human activities have profoundly altered the global environment. The term is currently undefined and is used only informally.

Anthropozoic (derived from anthrōpos 'human being' and zöion 'animal' or zoic 'life') was proposed as an era by Antonio Stoppani (1873) in the 1870s in recognition of the increasing power and effect of humanity on the Earth's systems. The epithet of -zoic is used to name units of era ranking, e.g. Palaeozoic, Mesozoic, Cenozoic, i.e. the rank above that of period, in turn an order above epoch.

Anthrocene is a term proposed by Revkin (1992) which had essentially the same meaning as Anthropocene.

Anthropocene deposits refer to those sediments and contained materials of various sources (e.g. plastics, metals, glass etc.) created by processes that reflect either human or natural agents, or a combination of the two, that accumulated during the time interval known as the Anthropocene.

Anthropogenic deposits refer to those sediments that have been created either directly or indirectly by human activities, but in which there is a dominant proportion of redeposited or novel material (Price et al. 2011, Ford et al. 2014). Such deposits may include artificial deposits/artificial ground (direct anthropogenic deposits). If natural processes are present, such as erosion and deposition within river systems, these may be considered to be indirect anthropogenic deposits, where human interaction, such as agriculture, deforestation, modification of river systems, influences the location and rates of such natural processes (Ford et al. 2014). The above terms are purely descriptive and none of have any time connotations and do not indicate whether they relate to Anthropocene or pre-Anthropocene time. Similarly the Anthropocene will include 'natural deposits' such as desert dune deposits, with no perceptible human influence.

Artificial deposits reflecting those sediments deposited directly and purposely by human activity and which may be associated with artificial ground, in which the ground surface has been modified either through deposition or excavation, or a combination of the two (Price et al. 2011, Ford et al. 2014). Edgeworth (2013) distinguishes the dominance of a cultural agency as the primary force in the production of artificial ground.

Made Ground and Worked Ground represent physical extents of, respectively, artificial deposits accumulated above the natural ground surface and excavations into this natural ground (Price et al. 2011, Ford $\boldsymbol{e t}$ al. 2014). These terms are used as part of a morphostratigraphical scheme used by the British Geological Survey to classify artificial deposits. Ford et al. (2014) consider the potential of developing truly lithostratigraphical schemes to classify artificial deposits. 